http://dx.doi.org/10.32929/2446-8355.2020v29n2p217-231

\title{
COMPOSTING AND VERMICOMPOSTING RESIDUES OF AÇAÍ AND BABASSU FOR SUSTAINABLE AGRICULTURE IN AMAZON
}

\author{
Adriana Lins Silva ${ }^{1}$, Rita de Cássia Costa Araújo $^{1}$, Marcos Rodrigues², Áurea Izabel Aguiar \\ Fonseca e Souza ${ }^{3}$, Wilton Pires da Cruz ${ }^{4}$
}

\begin{abstract}
${ }^{1}$ Discente graduação, Agronomia, Universidade Federal Rural da Amazônia (UFRA), campus Parauapebas, Pará.
${ }^{2}$ Docente, Agronegócio, Universidade Federal Rural da Amazônia (UFRA), campus Belém, Pará. *E-mail do autor correspondente: marcos.rodrigues@ufra.edu.br

${ }^{3}$ Docente, Fitotecnia, Universidade Federal Rural da Amazônia (UFRA), campus Parauapebas, Pará.

${ }^{4}$ Técnico Administrativo em Educação, Engenheiro Agrônomo, Universidade Federal Rural da Amazônia (UFRA), campus Parauapebas, Pará.
\end{abstract}

Recebido: 31/01/2020; Aceito: 18/05/2020

\begin{abstract}
Agroindustrial wastes in southeastern Amazon are abundant and there are policies encouraging proper disposal for such wastes for sustainable agriculture. In this study we compared the chemical parameters of composts resulting from composting and vermicomposting sheep manure added to agroindustrial wastes as a bulking agent. Piles of compost were created using sheep manure, fruit waste, and a bulking agent. The treatments consisted of compost piles of: Tc - sheep manure and fruit pulp; Ta - sheep manure, fruit pulp and triturated açaí seeds; Ts - sheep manure, fruit pulp and sawdust, and Tb - sheep manure, fruit pulp and babassu coconut residue. After 50 days, a fraction of the compost from each pile was transferred to vermireactors to compare processes. At the end of the experiment, samples were taken in triplicate from all treatments in both composting and vermicomposting units for chemical analysis. The assessed variables were daily temperature of compost piles and vermireators, $\mathrm{C} / \mathrm{N}$ ratio, Volatile solids (VS), total kjeldahl nitrogen (TKN), total phosphorus (TP), total potassium (TK), calcium $(\mathrm{Ca})$, magnesium $(\mathrm{Mg})$, sulfur $(\mathrm{S})$, iron $(\mathrm{Fe})$, copper $(\mathrm{Cu})$, zinc $(\mathrm{Zn})$, manganese $(\mathrm{Mn})$, boron (B). Sawdust-based and babassu-based compost, from composting process, has the lower time for stabilization (about 40 days), $\mathrm{pH}$ closer to neutral and more efficient in reducing the $\mathrm{C}: \mathrm{N}$ ratio than vermicomposts. Vermicomposting process increased the concentration of almost all nutrients in treatments, except for babassu-based compost.
\end{abstract}

Key words: Compost. C:N ratio. Babassu. Açaí. Sustainable agriculture.

\section{COMPOSTAGEM E VERMICOMPOSTAGEM DE RESÍDUOS DE AÇAÍ E BABAÇU PARA AGRICULTURA SUSTENTÁVEL NA AMAZÔNIA}

RESUMO: Os resíduos agroindustriais no sudeste da Amazônia são abundantes e existem políticas que incentivam o descarte adequado desses resíduos, para a agricultura sustentável. Neste estudo foram comparados parâmetros químicos dos compostos resultantes da compostagem e vermicompostagem de resíduos agroindustriais, com esterco de ovinos adicionados como agente de volume. Pilhas para compostagem foram montadas, utilizando-se 
esterco ovino, resíduos de frutas e agentes de volume. Os tratamentos consistiram em pilhas de composto de: Tc - esterco de ovelha e polpa de frutas; Ta - esterco de ovelha, polpa de frutas e sementes de açaí triturado; Ts - esterco de ovelha, polpa de frutas e serragem e Tb - esterco de ovelha, polpa de frutas e resíduo de coco babaçu. Após 50 dias, uma fração do composto de cada pilha foi transferida para vermireatores para comparar os processos. No final do experimento, as amostras foram coletadas em triplicata de todos os tratamentos, tanto nas unidades de compostagem quanto nas de vermicompostagem, para análise química. As variáveis avaliadas foram temperatura diária das pilhas de compostagem e dos vermireatores, razão C / N, sólidos voláteis (VS), nitrogênio kjeldahl total (TKN), fósforo total (TP), fósforo total $(\mathrm{TP})$, potássio total $(\mathrm{TK})$, cálcio $(\mathrm{Ca})$, magnésio $(\mathrm{Mg})$ ), enxofre $(\mathrm{S})$, ferro $(\mathrm{Fe})$, cobre $(\mathrm{Cu})$, zinco $(\mathrm{Zn})$, manganês $(\mathrm{Mn})$, boro $(\mathrm{B})$. O composto à base de serragem e babaçu, proveniente do processo de compostagem, apresenta menor tempo de estabilização (cerca de 40 dias), pH mais próximo do neutro e mais eficiente na redução da razão C:N do que nos vermicompostos. $\mathrm{O}$ processo de vermicompostagem aumentou a concentração de quase todos os nutrientes nos tratamentos, exceto o composto à base de babaçu.

Palavras-chave: Composto. Razão C:N. Babaçu. Açaí. Agricultura Sustentável.

\section{INTRODUCTION}

Organics waste, when improperly managed, can lead to negative impacts on environmental and human health through the contamination of water, soil, and air (RAJPUT; PRASAD; CHOPRA, 2009; RAMAN; NARAYANAN, 2008). Cycling techniques such as composting, vermicomposting, and anaerobic digestion (CAMPUZANO; GONZÁLEZMARTÍNEZ, 2015) have been developed to provide adequate disposal systems for organic wastes, and also contribute to energy production and the creation of viable agricultural compost (BATSTONE; VIRDIS, 2014; BLOUIN et al., 2019; NIGUSSIE et al., 2016).

Composting involves the degradation of organic matter through the action of microorganisms in an aerobic environment (EPSTEIN, 2011), some process includes different organisms (PEREIRA et al., 2019). Vermicomposting is the biological process of transforming organic waste into humic substances through the action of earthworms (BLOUIN et al., 2019; LV; XING; YANG, 2016). In both processes, the final product is an organic compost, which is rich in nutrients and can be used to improve the physical, chemical, and biological conditions of the soil for the production of vegetation (BLOUIN et al., 2019; DOMINGUEZ; EDWARDS, 2011; EDEN; GERKE; HOUOT, 2017). The use of organic compost also has positive environmental effects, due to the reuse of waste that could otherwise be improperly discarded (LIM; LEE; WU, 2016).

Previous studies have shown that vermicomposting can reduce greenhouse gas emissions, and a greater capacity for recycling of nitrogen (NIGUSSIE et al., 2016). In order to identify the components that guarantee the positive characteristics for soil quality maintenance and plant nutrition, physical-chemical parameters were studied of some bulk agents used in composting, including apple, rice, fruit bagasse residues, and food waste (ANTUNES et al., 2014) and different animal manures (HUANG; WANGB; HAN, 2011; WANG et al., 2016). 
In the Brazilian Amazon, there are some activities that produce organic wastes that can contribute positively to the environment and local agriculture through composting and vermicomposting processes. Babassu (Orbignya phalerada Mart.) is one of the most abundant palm trees found on land used for agriculture and livestock, in southeastern portion of the eastern Amazon (ANDERSON; MAY; BALICK, 1991). Its occurrence in abundance is directly associated with deforested area and degraded pastures in regeneration. Many of its products are used by quilombola populations (descendants of slave refugees), indigenous people and other family farmers, who practice extracting the fruit of this palm tree in this region (PORRO, 2019). It is also used for biodiesel production (LIMA et al., 2007). The main residues generated are the fruit peel and sawdust. Açaí palm (Euterpe oleracea Mart.) is one of the most important agricultural and extractive culture of the Amazonia, Pará state is the national leader in açaí production, with more than 141 thousand tons produced in 2017 (ARAUJO; SOUZA FILHO, 2018; INSTITUTO BRASILEIRO DE GEOGRAFIA E ESTATÍSTICA - IBGE, 2020). The main residue generated by this crop is the lumps resulting from the pulping (BUFALINO et al., 2018).

Very few, or nothing, is known about the chemical composition of açaí and babassu based composts. In order to contribute to the cycling of Amazonian waste products, and to produce substances for agronomic use, contributing to the sustainable development of family farmers in this region of the Amazonia, we aim to determine the chemical characteristics of the organic composts produced by composting and vermicomposting residues originating from agroindustrial activity, from the production or extraction of babassu, açaí fruits and wood from native species in the southeastern Pará, eastern Amazonia, Brazil.

\section{MATERIAL AND METHODS}

\section{Experiment setup}

The experiment was carried out between March and June 2018 in two distinct phases. The first phase consisted of combining different materials in piles for composting. The materials used were sheep manure, N-rich component, obtained from the animal production sector at the university; fruit pulp residues collected at a pulp processing cooperative, to enrich nutrients and natural moisture making the environment more attractive to decomposing organisms; triturated açaí seeds obtained from local açaí pulp traders, which have 95.58 organic matter, $48.27 \mathrm{C} / \mathrm{N}$ ratio and pH 5 (TEIXEIRA et al., 2005); sawdust from native Amazonian species, obtained from local logging industries, which have 98.03 organic matter, $123.77 \mathrm{C} / \mathrm{N}$ ratio and $\mathrm{pH} 5,45$ (TEIXEIRA et al., 2005) and, babassu coconut residues collected from a rural agroindustry which uses babassu to produce animal feed, very lignified material whose organic matter content and $\mathrm{C} / \mathrm{N}$ ratio are unknown. Using these waste products, four compost piles were formed with an approximate volume of $0.6 \mathrm{~m}^{3}$ each. Each compost pile represented a treatment of this experiment, and contained an organic residue as a source of variation (except for the control treatment $-\mathrm{T}_{\mathrm{c}}$ ) following the proportions below:

$\mathrm{T}_{\mathrm{c}}$ : sheep manure $(50 \%)+$ fruit pulp $(50 \%)$;

$\mathrm{T}_{\mathrm{a}}$ : sheep manure $(31 \%)+$ fruit pulp $(28 \%)+$ triturated açaí seeds $(41 \%)$;

$\mathrm{T}_{\mathrm{s}}$ : sheep manure $(31 \%)+$ fruit pulp $(28 \%)+$ sawdust $(41 \%)$; 
$\mathrm{T}_{\mathrm{b}}$ : sheep manure $(31 \%)+$ fruit pulp $(28 \%)+$ babassu coconut residue $(41 \%)$.

\section{Preparation of vermicomposting treatments}

After 50 days of composting, we started the second phase of the study. From each pile, 3 $\mathrm{kg}$ of fresh mass was randomly sampled and placed in 10 plastic vermireactors. Thirty earthworms (Eisenia andrei) which had clitella were then added to each vermireactor. The vermicomposting piles were incubated for 32 days, and the composting piles were incubated for more than 40 days. During the entire first and second phases, the daily temperature inside composting piles and vermireactors was recorded. The temperature measurements of the compost piles were made with a digital skewer thermometer at five points in each pile, while the ambient temperature was monitored with a mercury thermometer.

\section{Data collection}

At the end of the experiment, samples were taken in triplicate from all treatments in both composting and vermicomposting units for chemical analysis. All samples were dried at $65^{\circ} \mathrm{C}$ before chemical analysis. A suspension of $10 \mathrm{~g}$ of sample was stirred in $\mathrm{CaCl}_{2}$ solution $(0.01$ mol $\mathrm{L}^{-1}$ ) for 30 minutes, and then the $\mathrm{pH}$ was measured. Volatile solids (VS) was determined by ignition in muffle furnace $\left(550^{\circ} \mathrm{C}\right.$ for 4 hours).

Total Kjeldahl nitrogen (TKN) was determined by the Kjeldahl method. Total phosphorus (TP) was assessed colorimetrically with molybdovanadate phosphoric acid, and total potassium (TK) was assessed using a flame spectrophotometer. The elements calcium (Ca), magnesium $(\mathrm{Mg})$, sulfur $(\mathrm{S})$, iron $(\mathrm{Fe})$, copper $(\mathrm{Cu})$, zinc $(\mathrm{Zn})$, and manganese $(\mathrm{Mn})$ were assessed by atomic absorption spectrophotometry, and boron (B) was assessed using a digital spectrophotometer. All these methods were based on the Brazilian Manual of Analytical Methods for Fertilizers (BRASIL, 2014).

\section{Data analysis}

Statistical analyses were carried out using $\mathrm{R}$ software (version 3.5.1). Analysis of variance (ANOVA) was used to test for statistically significant differences between the treatments, and Fisher's least significant difference test (LSD test) was used for pairwise comparison of treatment means if significant differences were detected $(\mathrm{p}<0.05)$.

\section{RESULTS AND DISCUSSION}

\section{Temperature during decomposition process}

Data on the composting temperature for the various treatments indicate that, after five days, the compost piles reached the maximum temperatures (Figure 1). Açaí-based compost $\left(\mathrm{T}_{\mathrm{a}}\right.$ ) had higher temperatures (maximum of $49.24^{\circ} \mathrm{C}$ ) during almost all the composting process when compared with the other piles. We noted that $\mathrm{T}_{\mathrm{a}}$ compost reached temperature stabilization after 63 days, while the other treatments took about 40 days to reach stable temperatures (Figure 1). 


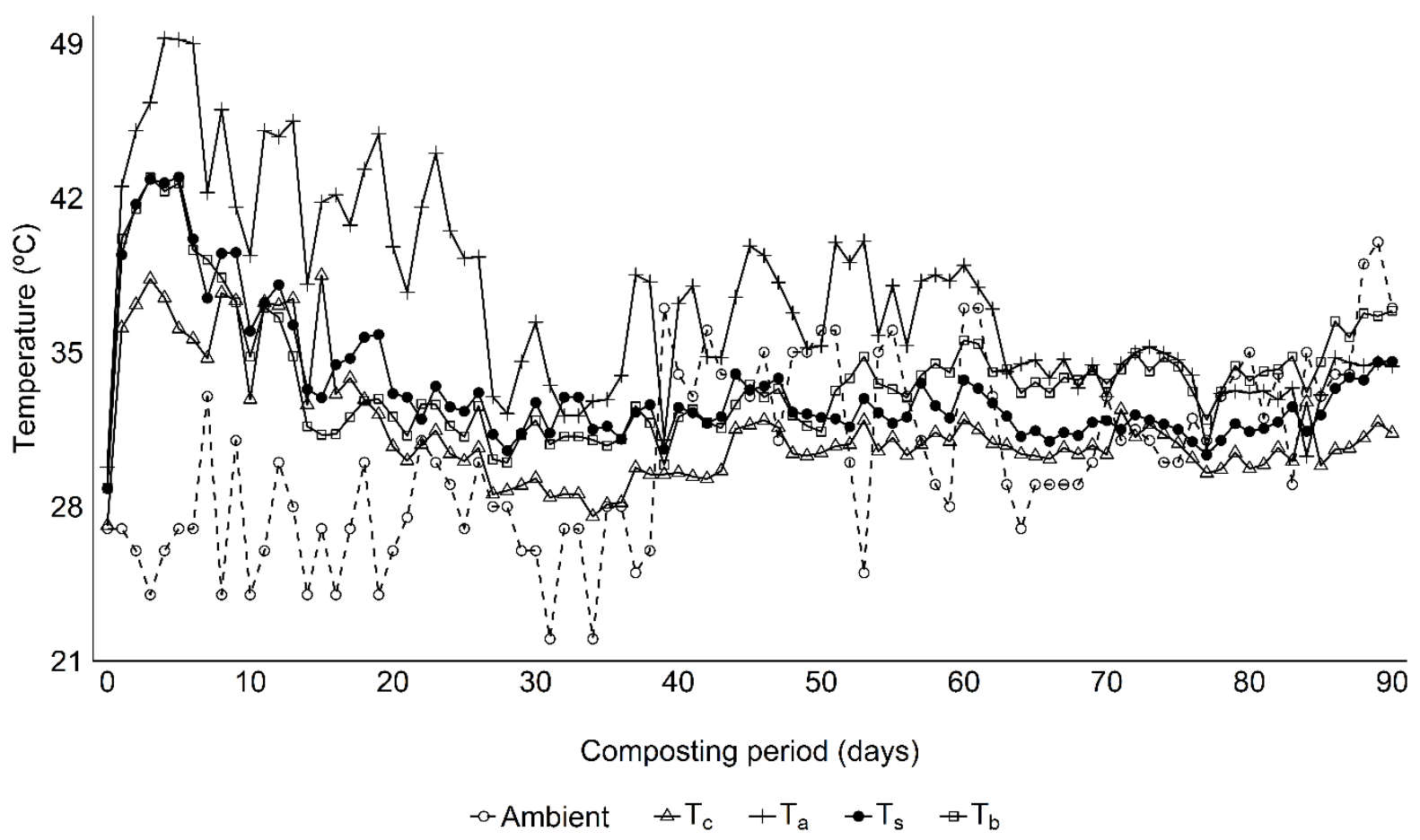

Figure 1. Temperature of the treatments and ambient during the composting process. $T_{c}$ : Sheep manure and fruit residues; $\mathrm{T}_{\mathrm{a}}$ : Sheep manure, fruit residues, and triturated açaí; $\mathrm{T}_{\mathrm{s}}$ Sheep manure, fruit residues, and sawdust; $\mathrm{T}_{\mathrm{b}}$ : Sheep manure, fruit residues, and babassu coconut. Source: Field collection data.

For vermicomposting, the temperatures in all treatments were within the acceptable range, and no large variations were observed $\left(\mathrm{T}_{\mathrm{c}}=30.07 \pm 1.17^{\circ} \mathrm{C} ; \mathrm{T}_{\mathrm{a}}=30.96 \pm 1.29^{\circ} \mathrm{C} ; \mathrm{T}_{\mathrm{s}}=\right.$ $30.52 \pm 1.26^{\circ} \mathrm{C}$ and $\mathrm{T}_{\mathrm{b}}=30.38 \pm 1.15^{\circ} \mathrm{C}$ ).

\section{Chemical characteristics of composting}

We observed that for the chemical parameter analysis in composting, the different treatments showed significant statistical differences between compost treatments for most nutrients (Table 1). Treatment açaí-based compost had the lowest C:N ratio (13.82), followed by based on babassu compost (16.56), control and based on sawdust compost (19.49 and 19.52, respectively). All treatments resulted in $\mathrm{pH}$ values that were close to neutral, with based on açaí compost differing slightly from the others. Only the volatile solids (VS), $\mathrm{Cu}$ and B variables did not differ between treatments. In Total Kjeldahl Nitrogen (TKN) the açaí-based and babassubased composts had the highest means, followed by control and based on sawdust compost. For total phosphorus (TP), the control and the açai-based compost obtained the highest means, followed by babassu-based compost and sawdust-based compost that had the lowest mean. With respect to total potassium (TK) the control had the highest mean, while for $\mathrm{Ca}, \mathrm{Mg}$ and Fe only control and sawdust-based compost differed from each other. 
Table 1. Means ( \pm Standard Deviation) of final characteristics of composting, after 90 days.

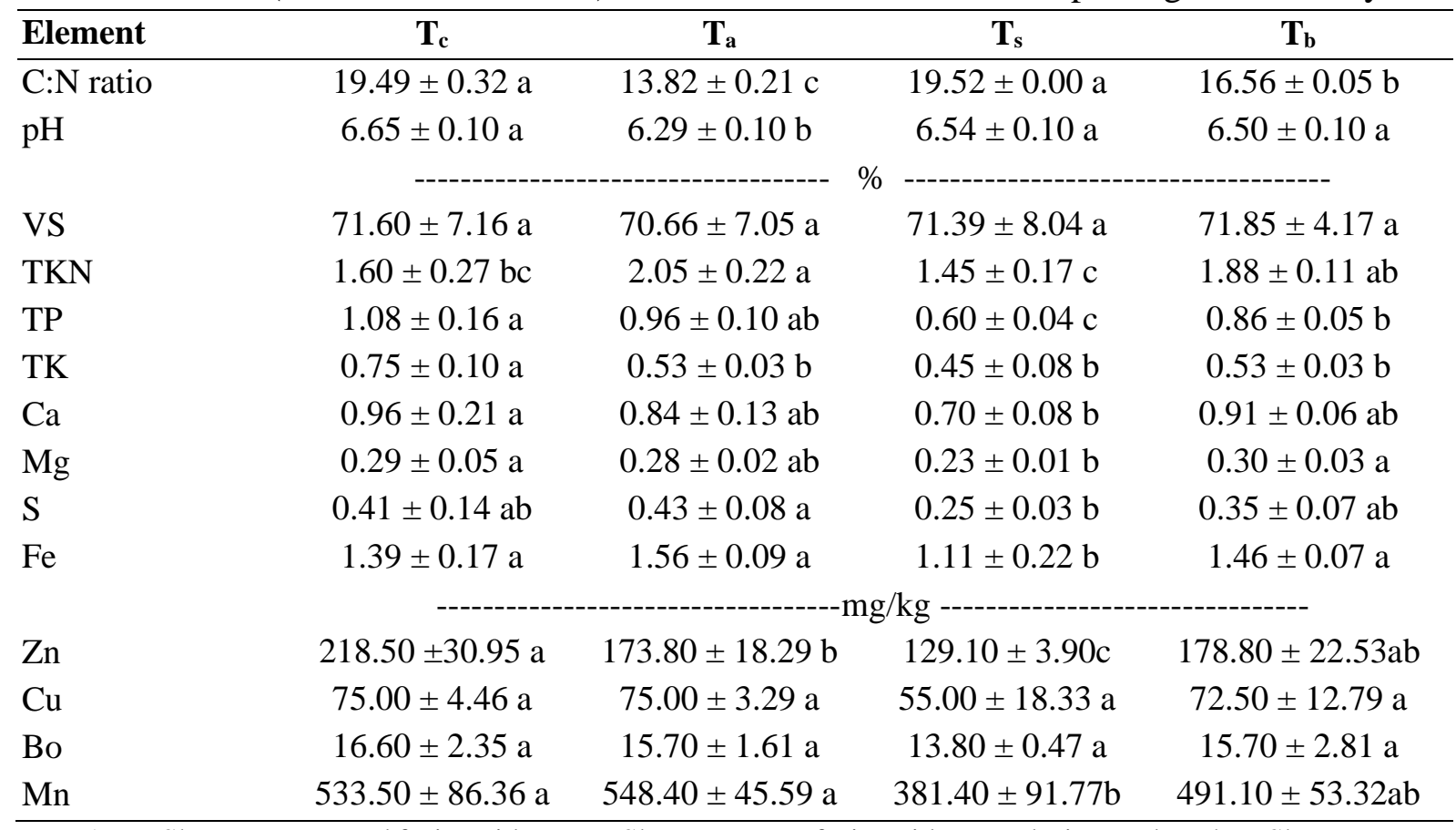

Note 1: $T_{c}$ : Sheep manure and fruit residues; $T_{a}$ : Sheep manure, fruit residues, and triturated açaí; $T_{s}$ Sheep manure, fruit residues, and sawdust; $\mathrm{T}_{\mathrm{b}}$ : Sheep manure, fruit residues, and babassu; VS $=$ Volatile solids; $\mathrm{TKN}=$ Total Kjeldahl nitrogen; $\mathrm{TP}=$ Total phosphorus; $\mathrm{TK}=$ Total potassium. Note 2: Means followed by the same letter on the same line do not differ statistically, LSD Fisher's test $(\mathrm{p}<0.05)$.

Source: Laboratory analysis data.

Only açaí-based compost and sawdust-based compost differed from each other for S. Zn control was statistically higher than açaí-based and sawdust-based composts, and açaí-based compost than sawdust-based composts. Mn sawdust-based composts had the lowest mean, having differed statistically from control and açaí-based compost (Table 1).

\section{Chemical characteristics of vermicomposting}

Chemical parameter analysis for vermicomposting we also observed between the different treatments and indicated that there were significant statistical differences between compost treatments for most nutrients (Table 2). After 32 days of vermicomposting, we found that the treatments control and açaí-based had the lowest $\mathrm{C}: \mathrm{N}$ ratio, 13.33 and 14.00, respectively, there is no difference between them. Babassu-based compost has the highest $\mathrm{C}: \mathrm{N}$ ratio (25.33) followed by sawdust-based compost (20.00). Sawdust-based and babassu-based compost had a pH that was close to neutral (6.63 and 6.68, respectively), there is no difference between them.

Açaí-based compost obtained the lowest $\mathrm{pH}$ (5.9) followed by control (5.39). For the VS babassu-based and sawdust-based composts had the highest values followed by açaí-based compost then control. However, for the TKN açaí-based compost has the highest value, next coming the control followed sawdust-based compost then babassu-based compost. Control treatment had the highest value for TP, followed by açaí-based compost then sawdust-based and babassu-based composts. TK and TP were statistically different between treatments in vermicomposting -except for TP sawdust and babassu treatment, which showed equal-. 
Control treatment had the highest and babassu-based compost had lowest concentration of $\mathrm{Ca}$, $\mathrm{Mg}, \mathrm{S}, \mathrm{Fe}, \mathrm{Zn}, \mathrm{Cu}, \mathrm{B}$ and Mn. However, B control did not differ from açaí-based and sawdustbased composts. While the Ca babassu-based compost did not differ from açaí-based and sawdust-based composts (Table 2).

Table 2. Means ( \pm Standard Deviation) of final characteristics of vermicomposting, after 32 days.

\begin{tabular}{|c|c|c|c|c|}
\hline Element & $\mathbf{T}_{\mathrm{c}}$ & $\mathbf{T}_{\mathrm{a}}$ & $\mathbf{T}_{\mathrm{s}}$ & $\mathbf{T}_{\mathrm{b}}$ \\
\hline $\mathrm{C}: \mathrm{N}$ ratio & $13.33 \pm 0.58 \mathrm{c}$ & $14.00 \pm 0.00 \mathrm{c}$ & $20.00 \pm 1.00 \mathrm{~b}$ & $25.33 \pm 2.89 \mathrm{a}$ \\
\hline $\mathrm{pH}$ & $5.90 \pm 0.06 b$ & $5.39 \pm 0.09 c$ & $6.63 \pm 0.02 \mathrm{a}$ & $6.68 \pm 0.03 \mathrm{a}$ \\
\hline VS & $57.03 \pm 0.45 c$ & $68.57 \pm 1.85 \mathrm{~b}$ & \% & $75.11 \pm 1.82 \mathrm{a}$ \\
\hline TKN & $2.34 \pm 0.12 \mathrm{~b}$ & $2.60 \pm 0.05 \mathrm{a}$ & $1.86 \pm 0.04 \mathrm{c}$ & $1.62 \pm 0.18 \mathrm{~d}$ \\
\hline TP & $1.88 \pm 0.07 \mathrm{a}$ & $1.33 \pm 0.03 b$ & $0.88 \pm 0.07 \mathrm{c}$ & $0.78 \pm 0.17 \mathrm{c}$ \\
\hline TK & $0.73 \pm 0.04 \mathrm{a}$ & $0.63 \pm 0.05 b$ & $0.50 \pm 0.05 \mathrm{c}$ & $0.38 \pm 0.00 \mathrm{~d}$ \\
\hline $\mathrm{Ca}$ & $1.38 \pm 0.04 \mathrm{a}$ & $0.92 \pm 0.14 \mathrm{c}$ & $1.18 \pm 0.09 b$ & $1.06 \pm 0.10 b c$ \\
\hline $\mathrm{Mg}$ & $0.38 \pm 0.04 \mathrm{a}$ & $0.30 \pm 0.01 b$ & $0.26 \pm 0.02 b c$ & $0.24 \pm 0.04 \mathrm{c}$ \\
\hline S & $0.63 \pm 0.07 \mathrm{a}$ & $0.46 \pm 0.01 b$ & $0.31 \pm 0.04 \mathrm{c}$ & $0.28 \pm 0.02 \mathrm{c}$ \\
\hline $\mathrm{Fe}$ & $1.27 \pm 0.18 \mathrm{a}$ & $0.84 \pm 0.06 b$ & $0.54 \pm 0.02 c$ & $0.53 \pm 0.11 \mathrm{c}$ \\
\hline & & 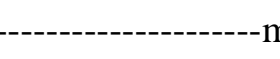 & ng/kg ---- & --------------- \\
\hline $\mathrm{Zn}$ & $319.53 \pm 2.83 a$ & $214.40 \pm 3.76 b$ & $145.70 \pm 5.16 \mathrm{c}$ & $134.97 \pm 23.42 \mathrm{c}$ \\
\hline $\mathrm{Cu}$ & $101.00 \pm 2.60 \mathrm{a}$ & $85.00 \pm 2.50 \mathrm{~b}$ & $53.33 \pm 1.44 \mathrm{c}$ & $50.83 \pm 6.29 c$ \\
\hline B & $9.57 \pm 0.40 \mathrm{a}$ & $10.40 \pm 1.37 \mathrm{a}$ & $9.37 \pm 0.96 \mathrm{ab}$ & $7.77 \pm 0.46 b$ \\
\hline $\mathrm{Mn}$ & $647.47 \pm 7.54 \mathrm{a}$ & $522.57 \pm 18.26 \mathrm{~b}$ & $382.23 \pm 13.77 \mathrm{c}$ & $299.13 \pm 67.02 \mathrm{~d}$ \\
\hline
\end{tabular}

Note 1: $\mathrm{T}_{\mathrm{c}}$ : Sheep manure and fruit residues; $\mathrm{T}_{\mathrm{a}}$ : Sheep manure, fruit residues, and triturated açaí; $\mathrm{T}_{\mathrm{s}}$ Sheep manure, fruit residues, and sawdust; $\mathrm{T}_{\mathrm{b}}$ : Sheep manure, fruit residues, and babassu coconut; VS = Volatile solids; TKN = Total Kjeldahl nitrogen; TP = Total phosphorus; TK = Total potassium; Tc. Note 2: Means followed by the same letter on the same line do not differ statistically, LSD Fisher's test $(\mathrm{p}<0.05)$.

Source: Laboratory analysis data.

\section{Advantages of vermicomposting shortly after composting Amazon residues}

For the sawdust-based and babassu-based composts, the composting process was more efficient in reducing the $\mathrm{C}: \mathrm{N}$ ratio in than the vermicomposting process (Tables 1 and 2). Control and açaí-based compost became acidic after vermicomposting, changing from 6.65 and 6.29 respectively to 5.90 and $5.29 \mathrm{pH}$ (Tables 1 and 2). In more than $70 \%$ of the evaluated nutrients there was a gain in concentration to control, açaí-based and sawdust-based composts. In contrast, only one evaluated nutrient $(\mathrm{Ca})$ obtained gain in the babassu-based compost. The açaí-based vermicomposting had a higher percentage gain in TP, followed by TKN, ZN and TK. Control had the highest average percentage gain in nutrient concentration $(27.03 \%)$. Babassu-based compost had the lowest average percentage gain in nutrient concentration ($25.17 \%$ ). All treatments obtained considerable loss of $\mathrm{Fe}$ and $\mathrm{B}$ nutrient concentration after vermicomposting, reaching averages above 40 and $38 \%$ loss for $\mathrm{Fe}$ and $\mathrm{B}$ respectively. Babassu-based compost experienced a significant reduction in Fe (-63.70), Zn (-44.80) and Mn (-39.09) concentrations. Similarly, açaí-based and sawdust-based composts for Fe (-46.15 and $-51.35 \%$, respectively) and B (-33.75 and -32.10 , respectively) and control for B $(-42.35 \%)$ (Table 3). 
Table 3. Nutrient percentage gain in vermicomposting.

\begin{tabular}{lcccc}
\hline Element & $\mathbf{T}_{\mathbf{c}}$ & $\mathbf{T}_{\mathbf{a}}$ & $\mathbf{T}_{\mathbf{s}}$ & $\mathbf{T}_{\mathbf{b}}$ \\
\hline $\mathrm{TKN}$ & -16.25 & 26.80 & 28.27 & -13.83 \\
$\mathrm{TP}$ & 74.07 & 38.54 & 46.66 & -9.30 \\
$\mathrm{TK}$ & -2.66 & 18.86 & 11.11 & -28.30 \\
$\mathrm{Ca}$ & 43.75 & 9.52 & 68.57 & 16.48 \\
$\mathrm{Mg}$ & 31.03 & 7.14 & 13.04 & -20.00 \\
$\mathrm{~S}$ & 53.65 & 6.97 & 24.00 & -20.00 \\
$\mathrm{Fe}$ & -8.63 & -46.15 & -51.35 & -63.70 \\
$\mathrm{Zn}$ & 46.24 & 23.36 & 12.86 & -24.51 \\
$\mathrm{Cu}$ & 34.66 & 13.33 & -3.03 & -29.89 \\
$\mathrm{~B}$ & -42.35 & -33.75 & -32.10 & -44.80 \\
$\mathrm{Mn}$ & 21.36 & -4.71 & 0.21 & -39.09 \\
\hline Mean & 27.03 & 5.44 & 10.75 & -25.17 \\
\hline
\end{tabular}

Source: Laboratory analysis data.

Temperature control in composting and vermicomposting is essential to maintain optimal conditions for these processes. In composting, it is possible to identify two distinct phases regarding the temperature, namely (1) the thermophilic phase, when the temperature rises above $40{ }^{\circ} \mathrm{C}$, indicating microbial activity in the decomposition of the residues (BERNAL et al., 1998). This phase is necessary to eliminate pathogens that may be present in the materials to be composted (NIGUSSIE et al., 2016); and (2) the mesophilic phase, when the temperature declines and stabilizes at ambient temperature (LIM; LEE; WU, 2016). In vermicomposting, temperature control is important because temperatures outside ideal range of survival increases the mortality and escape rate of earthworms (GARG; GUPTA, 2011).

The fast rise in temperatures in the beginning of the process demonstrates the microbial activity in the compost, contributing to the elimination of pathogens. In our study only control compost did not achieve the thermophilic phase (Figure 1), where the temperature must be above $40^{\circ} \mathrm{C}$ (BERNAL et al., 1998). The stabilization of the material for a long period of time contributes to the degradation of the residues used in the process that are rich in lignin and cellulose (babassu, açaí, and sawdust). Among the treatments with Amazonia wastes, sawdustbased and babassu-based compost has the lower time for stabilization (about 40 days), being an advantage compared to the acai-based compost. However, the latter was higher in nutrient concentration after the vermicomposting process (Table 2).

Dominguez and Edwards (2011) found that the optimal temperature for the earthworm $E$. fetida is $25^{\circ} \mathrm{C}$, and temperatures above $30^{\circ} \mathrm{C}$ can induce microbial activity. Garg and Gupta (2011) demonstrated that the environment can reduce the activity of earthworms, and higher temperatures reduce earthworm activity more than lower temperatures. The temperatures in the vermireactors were not significantly higher than $30^{\circ} \mathrm{C}$, so we can infer that the activity of the earthworms was close to the ideal during the experiment, not interfering in the results obtained in the vermicomposting process

When using composts for agricultural purposes, it is necessary to check whether the $\mathrm{pH}$ is in the acceptable range for the plants (GODLEWSKA et al., 2017). The results regarding the 
$\mathrm{pH}$ in the different treatments are similar to those of Bustamante et al. (2013), who found $\mathrm{PH}$ values which ranged from 6.4 to 6.9 in composting treatments with solid fractions of the digestate and different bulking agents. Changes in $\mathrm{pH}$ can occur due to volatilization or mineralization of organic nitrogen and degradation of organic acids due to microbial activity (SINGH; KALAMDHAD, 2014; ZHANG et al., 2016). A higher relative proportion of fruit pulps could increase the acidity of composts in different treatments. Hanc and Chadimova (2014), using wheat straw and apple residues, obtained compost with a slightly basic pH (7.2), and composts using only apple residue had a more acid $\mathrm{pH}$ (6.7). The most likely explanation for the high acidity of treatment control (with only sheep manure and fruit residues), on vermicomposting, was that the presence of fruit pulp in the initial composting piles could have increased the concentration of organic acids, reducing the $\mathrm{pH}$ in treatments in this experiment. Brazilian law (IN-SDA 25/2009) allows the use of correctives in organic composts for agricultural use. Açaí-based compost obtained the lowest $\mathrm{pH}$ (5.39) should be used with caution in agriculture, especially in the Amazon. Tropical soils are naturally very acidic and in the case of the Amazon this gets even worse which makes nutrient absorption difficult, despite their availability in the Amazonian soils (LUIZÃO; LUIZÃO; PROCTOR, 2007).

Mineralization of materials and the consumption of organic matter by microbial activity (composting) and earthworms (vermicomposting) resulted in a higher concentration of nitrogen and reduction of carbon. Cestonaro et al. (2017) found that mixtures of sheep manure with higher levels of bovine manure resulted in a lower $\mathrm{C}: \mathrm{N}$ ratio. Previous studies have reported that açaí seeds have higher nitrogen concentrations than babassu mesocarp and sawdust (RAMBO; SCHMIDT; FERREIRA, 2015; VIEIRA et al., 2011; WANG et al., 2016). This explains the fact that açaí-based compost has the lowest $\mathrm{C}$ : $\mathrm{N}$ ratio after composting and vermicomposting (Table 1 and 2). In this study, vermicomposting soon after composting was not favorable for babassu-based compost because reducing $\mathrm{N}$ concentration which increased $\mathrm{C}$ : $\mathrm{N}$ ratio.

Vermicomposting presented a higher nutrients concentration than composting (Table 3). López-Cano et al. (2016) analyzed the composting of olive residues, which are rich in lignocellulose, with sheep manure and biochar, and recorded nitrogen concentrations between 2.40 and 2.69\%. Lazcano, Gómez-Brandón, and Domínguez (2008) noted that the nitrogen concentrations in vermicomposting $(2.8 \%)$ was higher than in composting process $(2.2 \%)$. The results in these literatures regarding TKN are close to vermicomposting açaí-based compost, showing potential of using triturated açaí as material for composting in sustainable agricultural uses in southeastern Pará. The lower concentration of TKN in composting process when compared to vermicomposting (Tables 1 and 2) do not exclude the use of açaí-based compost, from the composting process, in agricultural uses. The $\mathrm{N}$ from organic compost (from composting or vermicomposting) includes the mineral $\mathrm{N}$, already existing in the composts $(\mathrm{N}$ $\mathrm{NH} 4+$ and N-NO3 -), and the organic $\mathrm{N}$ that mineralizes after incorporation into the soil (AMLINGER et al., 2003). Organic N consists of an easily mineralizable fraction, which contributes to crop nutrition in the short term, and another that is resistant to decomposition that can take months or years to be mineralized, which contributes to increase soil fertility in the long run (AMLINGER et al., 2003). Considering the low fertility condition of most Amazonian soils, this second characteristic of organic $\mathrm{N}$ is extremely relevant for improving long-term 
fertility and survival of microorganisms beneficial to agricultural crops, which depend on this N.

The TP concentrations in all treatments were lower than found in some previous studies, including those by Wang et al. (2016), who found TP concentrations in composting of over $2 \%$, and Bustamante et al. (2013), who found TP concentrations between 2.64 and 3.78\%. However, the TP concentrations in all treatments in this study were higher than those reported by Kouba et al. (2018), who reported TP concentrations between 0.5 and $1.6 \%$.

Cestonaro et al. (2017) obtained TK concentrations between 0.42 and $0.6 \%$, related to açaí-based compost context. In organic composts $\mathrm{K}$ is not incorporated into organic matter that is why is much more available for plant uptake than nitrogen and phosphorus. However, $\mathrm{K}$ can be easily leached out of the compost only upon contact with water (MANGAN et al., 2013).

The highest concentration of zinc $(0.032 \%)$ and copper $(0.01 \%)$ in control were likely due to the higher proportion of sheep manure, as a sheep consume feeds that contain these elements (GIROTTO et al., 2010). Excess $\mathrm{Zn}$ and $\mathrm{Cu}$ can lead to soil toxicity in agricultural systems, and, as such, when using biofertilizers, care is required to avoid excessive use over time, as they are a source for accumulation of such elements (GIROTTO et al., 2010). Some studies have already analyzed the use of plants with potential phytoextraction of elements in contaminated soils (ZALEWSKA; NOGALSKA, 2014), and the use of sheep manure to reduce the mobility of $\mathrm{Zn}$ in the soil in areas in which mining activity increased the concentrations of Zn, impacting agriculture (ELOUEAR et al., 2016). The increased proportion of organic matter in açaí-based, sawdust-based and babassu-based composts contributes to reducing the $\mathrm{Zn}$ and $\mathrm{Cu}$ concentration and means that these are better options for agricultural use.

Vermicomposting soon after composting caused a significant reduction in $\mathrm{Fe}$ and $\mathrm{B}$ concentration. In plants B is responsible for developing roots, metabolizing carbohydrates, transporting sugars, synthesizing nucleic acids (DNA and RNA), phytohormones, forming cell walls and cell division (DUGGER, 1973; THOMAS; MURRAY; MURPHY, 2017). In plants $\mathrm{Fe}$ It is essential for protein synthesis and helps to form some enzymatic respiratory systems, has functions in plant respiration, photosynthesis and energy transfer, it is deficient in soils with plenty of organic matter (HUANG; WANGB; HAN, 2011; THOMAS; MURRAY; MURPHY, 2017). This suggests an explanation for the reduced concentration of this mineral after vermicomposting, apparently the greater decomposition of the organic matter (humification and mineralization) by the action of earthworms disadvantages the presence of this mineral in the compost (Table 3).

Overall, for most treatments, vermicomposting was obviously positive for nutrient concentration gain (63.64\% of the tested nutrients increased their concentration) (Table 3). However, it is not recommended for babassu-based compost for later use in agriculture, which was lost in at the concentration of over $90 \%$ of the tested nutrients. Babassu coconut has several applications in various fields, including biomass energy source (PROTÁSIO et al., 2014), animal feed (PARENTE et al., 2017) and, as the results of this work showed, the babassu-based compost from the composting process, can be used in agriculture. 
Earthworm humus is better priced and more widely accepted in the market than composting compost. For Amazonian family farmers, who have at their disposal large quantities of açaí seeds and babassu residues, they can use the results of this work as a basis for valuing the product generated from the composting of these residues. In addition to ensuring greater value addition of açaí-based compost by producing humus with vermicomposting. Composting and vermicomposting are efficient processes to reduce inappropriate disposal of organic wastes from agroindustry processes in the Amazonian region with appropriate incentive to develop sustainable agriculture. In addition, the results of this work show that vermicomposting improves qualitatively (concentration of nutrients) the organic compost that has gone through the composting process, however, reservations should be made, as it had the opposite effect for babassu-based compost.

\section{CONCLUSION}

Sawdust and babassu-based residues compost presented lowest time to material stabilization (40 days, compared with 63 days in açaí-based compost). Furthermore, composting of these materials showed a greater reduction of $\mathrm{C}: \mathrm{N}$ ratio than vermicomposting process and $\mathrm{pH}$ close to neutrality.

With exception of the babassu treatment, vermicomposting process proved to be an efficient method to improve concentrations of macronutrients and most micronutrients.

\section{REFERENCES}

AMLINGER, F.; GÖTZ, B.; DREHER, P.; GESZTIA, J.; WEISSTEINER, C. Nitrogen in biowaste and yard waste compost: dynamics of mobilisation and availability a review. European Journal of Soil Biology, Issy-les-Moulineaux, v. 39, n. 3, p.107-116, 2003.

ANDERSON, A.; MAY, P.; BALICK, M. J. The Subsidy from nature: Palm forests, peasantry, and the development of Amazon frontier. New York: Columbia University Press, 1991. $233 \mathrm{p}$.

ANTUNES, R. M, CASTILHOS, R. M.; CASTILHOS, D. D.; LEAL, O. A.; DICK, D. P.; ANDREAZZA, R. Chemical changes of humic acid during vermicomposting process of organic residues. Engenharia Sanitaria e Ambiental, Rio de Janeiro, v. 20, n. 4, p.699-708, 2014.

ARAUJO, D. DO N.; SOUZA FILHO, H. M. Direcionadores de competitividade na cadeia produtiva da polpa do açaí no nordeste paraense. Custos e @ gronegócio online, Recife, v. 14, n. 4, p.98-126, 2018.

BATSTONE, D. J.; VIRDIS, B. The role of anaerobic digestion in the emerging energy economy. Current Opinion in Biotechnology, Londres, v. 27, p.142-149, 2014.

BLOUIN, M; BARRERE, J.; MEYER, N.; LARTIGUE, S.; BAROT, S.; MATHIEU, J. Vermicompost significantly affects plant growth. A meta-analysis. Agronomy for Sustainable Development, Paris, v. 39, n. 4, p.34, 2019. 
BRASIL. Manual de métodos analíticos oficiais para fertilizantes minerais, orgânicos, organominerais e corretivos. Brasília: MAPA/ SDA/CGAL, 2014. 223 p.

BUFALINO, L.; GUIMARÃES, A. A.; Silva; B. M. S.; SOUZA, R. L. F.; MELO, I. C. N. A.; OLIVEIRA, D. N. P. S.; TRUGILHO, P. F. Local variability of yield and physical properties of açaí waste and improvement of its energetic attributes by separation of lignocellulosic fibers and seeds. Journal of Renewable and Sustainable Energy, Melville, v. 10, n. 5, p.53102, 2018.

BUSTAMANTE, M. A.; RESTREPO, A. P.; ALBURQUERQUE, J. A.; PÉREZ-MURCIA, M. D.; PAREDES, C.; MORAL, R.; BERNAL, M. P. Recycling of anaerobic digestates by composting: effect of the bulking agent used. Journal of Cleaner Production, Oxford, v. 47, p. 61-69, 2013.

CAMPUZANO, R.; GONZÁLEZ-MARTÍNEZ, S. Extraction of soluble substances from organic solid municipal waste to increase methane production. Bioresource Technology, Oxford, v. 178, p.247-253, 2015.

CESTONARO, T.; COSTA, M. S. S. M.; COSTA, L. A. M.; PEREIRA, D. C.; ROZATTI, M. A. T.; MARTINS, M. F. L. Addition of cattle manure to sheep bedding allows vermicomposting process and improves vermicompost quality. Waste Management, Oxford, v. 61, p.165-170, 2017.

DOMINGUEZ, J.; EDWARDS, C. A. Biology and Ecology of Earthworm Species Used for Vermicomposting. In: EDWARDS, C. A.; ARANCON, N. Q.; SHERMAN, R. (Eds.). . Vermiculture Technology: Earthworms, Organic Wastes, and Environmental Management. Boca Raton: CRC Press, 2011. cap. 3, p. 27-40.

DUGGER, W. M. Functional Aspects of Boron in Plants. In: KOTHNY, Evaldo L. (Ed.). . Trace Elements in the Environment. Washington: American Chemical Society, 1973. cap. 7, p. 112-129.

EDEN, M.; GERKE, H. H.; HOUOT, S. Organic waste recycling in agriculture and related effects on soil water retention and plant available water: a review. Agronomy for Sustainable Development, Paris, v. 37, n. 2, p.11, 2017.

ELOUEAR, Z; BOUHAMED, F.; BOUJELBEN, N.; BOUZID, J. Application of sheep manure and potassium fertilizer to contaminated soil and its effect on zinc, cadmium and lead accumulation by alfalfa plants. Sustainable Environment Research, Pequim, v. 26, n. 3, p.131-135, 2016.

EPSTEIN, E. Industrial Composting: Environmental Engineering and Facilities Management. Boca Raton: CRC Press, 2011. 340 p.

GARG, V. K.; GUPTA, R. Effect of temperature variations on vermicomposting of household solid waste and fecundity of eisenia fetida. Bioremediation Journal, Philadelphia, v. 15, n. 3, p.165-172, 2011.

GIROTTO, E.; CERETTA, C.A.; BRUNETTO, G.; SANTOS, D. R.; SILVA, L. S.; LOURENZI, F.; VIEIRA, R. C. B.; SCHMATZ, R. Acúmulo e formas de cobre e zinco no solo após aplicações sucessivas de dejeto líquido de suínos. Revista Brasileira de Ciência do Solo, 
Viçosa, v. 34, n. 3, p.955-965, 2010.

GODLEWSKA, P.; SCHMIDT, H. P.; OK, Y. S.; OLESZCKUK, P. Biochar for composting improvement and contaminants reduction. A review. Bioresource Technology, Oxford, v. 246, p.193-202, 2017.

HANC, A.; CHADIMOVA, Z. Nutrient recovery from apple pomace waste by vermicomposting technology. Bioresource Technology, Oxford, v. 168, p.240-244, 2014.

HUANG, G.; WANGB, X.; HAN, L. Rapid estimation of nutrients in chicken manure during plant-field composting using physicochemical properties. Bioresource Technology, Oxford, v. 102, p.1455-1461, 2011.

INSTITUTO BRASILEIRO DE GEOGRAFIA E ESTATÍSTICA - IBGE. Sistema IBGE de Recuperacao automatica-SIDRA. Disponível em: http://www.sidra.ibge.gov.br/. Acesso em: 17 abr. 2020.

KOUBA, A.; LUNDA, R.; HLAVÁČ, D.; KUKLINA, I.; HAMÁČKOVÁ, J.; RANDÁK, T.; KOZÁK, P.; KOUBOVÁ, A.; BUŘIČ, M. Vermicomposting of sludge from recirculating aquaculture system using Eisenia andrei: Technological feasibility and quality assessment of end-products. Journal of Cleaner Production journal, Oxford, v. 177, p.665-673, 2018.

LAZCANO, C.; GÓMEZ-BRANDÓN, M.; DOMÍNGUEZ, J. Comparison of the effectiveness of composting and vermicomposting for the biological stabilization of cattle manure. Chemosphere, Kidlington, v. 72, n. 7, p.1013-1019, 2008.

LIM, S. L.; LEE, L. H.; WU, T. Y. Sustainability of using composting and vermicomposting technologies for organic solid waste biotransformation: recent overview, greenhouse gases emissions and economic analysis. Journal of Cleaner Production, Oxford, v. 111, p.262-278, 2016.

LIMA, J. R. O.; SILVA, R. B.; SILVA, C. C. M.; SANTOS, L. S. S.; SANTOS JUNIOR, J. R.; MOURA, E. M.; MOURA, C. V. R. Biodiesel de babaçu (Orbignya sp.) obtido por via etanólica. Química Nova, São Paulo, v. 30, n. 3, p.600-603, 2007.

LÓPEZ-CANO, I.; ROIG, A.; CAYUELA, M. L.; ALBUQUERQUE, J. A.; SÁNCHEZMONEDERO, M. A. Biochar improves N cycling during composting of olive mill wastes and sheep manure. Waste Management, Oxford, v. 49, p.553-559, 2016.

LUIZÃO, F. J.; LUIZÃO, R. C. C.; PROCTOR, J. Soil Acidity and Nutrient Deficiency in Central Amazonian Heath Forest Soils. Plant Ecology, Kidlington, v. 192, n. 2, p.209-224, 2007.

LV, B.; XING, M.; YANG, J. Speciation and transformation of heavy metals during vermicomposting of animal manure. Bioresource Technology, Oxford, v. 209, p.397-401, 2016.

NIGUSSIE, A; KUYPER, T. W.; BRUUH, S.; NEERGAARD, A. Vermicomposting as a technology for reducing nitrogen losses and greenhouse gas emissions from small-scale composting. Journal of Cleaner Production, Oxford, v. 139, p.429-439, 2016.

PARENTE, M. O. M.; PARENTE, H. N.; GERUDE NETO, O. A.; CARVALHO, P. A.; 
GOMES, R. M. S.; MOREIRA FILHO, M. A.; SANTOS, V. L. F.; ZANINE, A. M.; FERREIRA, D. J.; OLIVEIRA, G. S.; ARAÚJO, J. S. Effect of increasing levels of babassu mesocarp flour on feed intake, nutrient digestibility, and rumen fermentation in sheep. Journal of Animal Science, Cary, v. 95, n. suppl 4, p.336, 2017.

PEREIRA, C. M. S.; ANTUNES, L. F.; SOARES, M. S.; AQUINO, A. M.; LEAL, M. A. A. Eficiência das larvas de besouro coprófago na compostagem do esterco de coelho. Cultura Agronômica: Revista de Ciências Agronômicas, Ilha Solteira, v. 28, n. 3, p.354-366, 2019.

PEROBELLI, F. S.; MATTOS, R. S.; FARIA, W. R. Interações energéticas entre o estado de Minas Gerais e o restante do Brasil: uma análise inter-regional de insumo-produto. Economia Aplicada, Ribeirão Preto, v. 11, n. 1, p.113-130, 2007.

PORRO, R. A economia invisível do babaçu e sua importância para meios de vida em comunidades agroextrativistas. Boletim do Museu Paraense Emílio Goeldi. Ciências Humanas, Belém, v. 14, n. 1, p.169-188, 2019.

PROTÁSIO, T. P.; TRUGILHO, P. F.; CÉSAR, A. A. S. C.; NAPOLI, A.; MELO, I. C. N. A.; SILVA, M. G.. Babassu nut residues: potential for bioenergy use in the North and Northeast of Brazil. SpringerPlus, Cham, v. 3, n. 1, p.124, 2014.

RAJPUT, R.; PRASAD, G.; CHOPRA, A. K. Scenario of solid waste management in present Indian context. Caspian Journal of Environmental Sciences, Rasht, v. 7, n. 1, p.45-53, 2009.

RAMAN, N.; NARAYANAN, D. S. Impact of solid waste effect on ground water and soil quality nearer to Pallavaram solid waste landfill site in Chennai. Rasayan Journal of Chemistry, Jaipur, v. 1, n. 4, p.828-836, 2008.

RAMBO, M. K. D.; SCHMIDT, F. L.; FERREIRA, M. M. C. Analysis of the lignocellulosic components of biomass residues for biorefinery opportunities. Talanta, Amsterdan, v. 144, p.696-703, 2015.

SINGH, W. R.; KALAMDHAD, A. S. Potential for composting of green phumdi biomass of Loktak lake. Ecological Engineering, Amsterdan, v. 67, p.119-126, 2014.

TEIXEIRA, L. B.; GERMANO, V. L. C.; OLIVEIRA, R. F. de; FURLAN JUNIOR, J. Processos de Compostagem Usando Resíduos das Agroindústrias de Açaí e de palmito do Açaizeiro: Circular Técnica. Belém: [s.n.]. 6 p.

THOMAS, B.; MURRAY, B. G.; MURPHY, D. J. Encyclopedia of Applied Plant Sciences. 2. ed. Amsterdam: Elsevier Academic Press, 2017. 1706 p.

VIEIRA, A. P.; SIRLANE, A. A. S.; BEZERRA, C. W. B.; SILVA, H. A. S.; CHAVES, J. A. P.; MELO, J. C. P.; SILVA FILHO, E. C.; AIROLDI, C. Epicarp and Mesocarp of Babassu (Orbignya speciosa): Characterization and Application in Copper Phtalocyanine Dye Removal. Journal of the Brazilian Chemical Society, São Paulo, v. 22, n. 1, p.21-29, 2011.

WANG, Q.; LI, R.; CAI, H.; AWASHTJ, M. K.; ZHANG, Z.; WANG, J. J.; ALI, A.; AMANULLAH, M. Improving pig manure composting efficiency employing Ca-bentonite. Ecological Engineering, Amsterdan, v. 87, p.157-161, 2016.

ZALEWSKA, M.; NOGALSKA, A. Phytoextraction potential of sunflower and white mustard 
plants in zinc-contaminated soil. Chilean journal of agricultural research, Santiago, v. 74, n. 4, p.485-489, 2014.

ZHANG, J.; CHEN, G.; SUN, H.; ZHOU, S.; ZOU, G.Straw biochar hastens organic matter degradation and produces nutrient-rich compost. Bioresource Technology, Oxford, v. 200, p.876-883, 2016. 